\title{
PENGEMBANGAN MEDIA EVALUASI PEMBELAJARAN MATEMATIKA BERBASIS GOOGLE FORMULIR
}

\section{DEVELOPMENT OF MATHEMATICS LEARNING MEDIA EVALUATION BASED ON GOOGLE FORM}

\author{
Nurhidayat $^{\text {a }}$, Nani Ratnaningsih ${ }^{\mathrm{b}}$, Khomstun Ni'mah ${ }^{\mathrm{c}}$ \\ ${ }^{a}$ Prodi Magister Pendidikan Matematika, Universitas Siliwangi \\ J1. Siliwangi No. 24, Tasikmalaya 46115, Indonesia, hidayatnur27011984@gmail.com \\ ${ }^{\mathrm{b}}$ Prodi Magister Pendidikan Matematika, Universitas Siliwangi \\ Jl. Siliwangi No.24, Tasikmalaya 46115, Indonesia, naniratnaningsih@ unsil.ac.id \\ ${ }^{\mathrm{c}}$ Prodi Magister Pendidikan Matematika, Universitas Siliwangi \\ J1. Siliwangi No. 24, Tasikmalaya 46115, Indonesia, khomsatunnimah@unsil.ac.id
}

\begin{abstract}
ABSTRAK
Penelitian ini bertujuan untuk mengembangkan media dan evaluasi pembelajaran berbasis google formulir pada materi logika matematika. Penelitian ini adalah penelitian pengembangan. Prosedur dalam penelitian ini terdiri dari analisis produk yang dikembangkan, mengembangkan produk awal, dan uji coba produk. teknik pengambilan data adalah wawancara, tes, dan dokumentasi. Sedangkan teknik analisis data menggunakan deskriptif persentasi. Penelitian ini dilakukan pada kelas XI.AKL di SMK Pasundan 1 Banjar. Subjek penelitian ini adalah sembilan peserta didik. Hasil validasi ahli media dan ahli materi menunjukkan bahwa media pembelajaran berbasis google form yang dikembangkan valid, Kevalidan media google form tersebut didasarkan pada hasil validasi ahli media dan ahli materi dengan diperoleh rata-rata skor $\geq 3 \geq$ 3untuk setiap aspek yang dinilai dan hasil penelitianya menunjukkan 6 orang peserta didik mendapatkan skor di atas KKM. Media evaluasi pembelajaran matematika berbasis google form sudah melalui tahapan validasi ahli media dan ahli materi serta masuk dalam kategori layak digunakan sebagai media evaluasi dan pembelajaran matematika dan mampu memotivasi peserta didik untuk belajar matematika.
\end{abstract}

Kata Kunci : Google Formulir, Media dan Evaluasi Pembelajaran

\section{ABSTRACT}

This study aims to develop media and Google-based learning evaluation forms on mathematical logic material. This research is a research development. The procedure in this study consisted of analyzing the product developed, developing the initial product, and testing the product. Data collection techniques are interviews, tests, and documentation. While the data analysis technique uses descriptive percentages. This research was conducted in class XI.AKL at SMK Pasundan 1 Banjar. The subjects of this study were nine students. The results of the validation of media experts and material experts showed that the Google form-based learning media that were developed were valid, and the results of the study showed that 6 students got scores above the KKM.

Keywords: Google Form, Media and Learning Evaluation 


\section{Pendahuluan}

Pada saat ini dunia sedang dilanda pandemi covid 19 termasuk di Indonesia sehingga mengakibatkan sekolahsekolah, termasuk sekolah tempat saya mengajar menjadi tidak beroperasi, ditutup untuk sementara, tidak ada kegiatan belajar mengajar. Dengan tujuan untuk menimimalisir penyebaran wabah virus corana, namun konsekuensinya sekolah boleh di tutup tetapi pembelajaran tetap di lakukan dengan jarak jauh (pembelajaran daring). Menjawab pandemi ini, Menteri Pembelajaran serta Kebudayaan Ayah Nadiem Makarim sudah menerbitkan Pesan Edaran( SE) salah satunya SE Nomor. 4 Tahun 2020 yang berisi Penerapan Kebijakan Pembelajaran pada Masa Darurat Penyebaran Coronavirus Disease ( Covid19). isi dari surat tersebut diantaranya menyangkut proses pendidikan dari rumah lewat Pendidikan Jarak Jauh( PJJ) yang dicoba dari tingkatan pendidikan dasar hingga pendidikan tinggi. Suka ataupun tidak suka, pendidikan yang umumnya dicoba di ruang kelas berbatas bilik secara tatap muka, saat ini berpindah pada kelas online secara synchronous maupun asynchronous. Sesungguhnya PJJ sendiri tidaklah sesuatu yang baru dalam pendidikan tinggi, cocok dengan UU Nomor. 12 Tahun 2012 tentang pendidikan tinggi serta Permendikbud Nomor. 109 Tahun 2013 tertuang kalau PJJ ialah proses pembelajaran yang dicoba secara jarak jauh lewat pemakaian bermacam media komunikasi. Prinsip pelaksanaan Belajar Dari Rumah (BDR) diantaranya : Kegiatan Belajar Dari Rumah dilaksanakan untuk memberikan pengalaman belajar yang bermakna bagi siswa,tanpa terbebani tuntutan menuntaskan seluruh capaian kurikulum. Kegiatan pembelajaran adalah suatu proses yang mengandung hubungan timbal balik antara peserta didik dengan guru, yang bersifat edukatif, yang dapat dilakukan di dalam maupun di luar kelas. Interaksi edukatif tidak hanya sebatas dalam penyampaian nilai pengetahuan tetapi juga nilai-nilai kehidupan. Suatu pembelajaran dikatakan efektif jika tujuan dari pembelajarannya sudah tercapai, Agar pembelajaran menjadi efektif, guru dituntut untuk mampu memilih strategi, metode, dan media yang tepat sesuai dengan bahan yang akan disampaikan. Kemampuan guru dalam merancang dan melaksanakan pembelajaran sangat menentukan apakah pembelajaran tersebut akan efektif atau tidak.

Sesuai dengan tuntutan Kurikulum Tahun 2013, melalui Permendikbud yang terakhir yaitu nomor 22 tahun 2016 tentang standar proses 
pembelajaran bagi guru guru. Pada permen tersebut, guru diharuskan melaksanakan proses pembelajaran berbasis IT dengan menggunakan Model Problem Based Learning (Pembelajaran Berbasis Masalah), Discovery Learning/Inquiry Learning (Pembelajaran Menemukan), dan menggunakan Scientific Aproach (pendekatan saintifik). Dengan demikian, dalam proses pembelajaran guru bertindak sebagai fasilitator supaya peserta didik dapat menemukan dan membangun pengetahuannya, melalui media yang dipersiapkan oleh guru, belajar dimulai dari masalah yang dikaitkan dengan kehidupan sehari-hari dengan menggunakan pendekatan Saintifik. Siswa harus terlibat aktif mencari, menemukan dan membangun konsep, belajar tidak hanya sekedar menghapal, guru tidak begitu saja memberikan langsung pengetahuan kepada siswa tetapi siswalah yang harus aktif membangun pengetahuannya. Belajar seperti ini sesuai dengan teori belajar konstruktivisme, Jerome Bruner, dan Vygotsky (Trianto, 2011). Dalam kurikulum 2013, pemerintah menuntut guru untuk mampu mengintegrasikan pembelajaran dengan penggunaan teknologi informasi dan komunikasi (TIK). Pemanfaatan TIK dalam pembelajaran diharapkan dapat meningkatkan pemahamannya terhadap materi yang di pelajari dan menumbuhkan rasa senang dan ketertarikan peserta didik. Pemanfaatan teknologi dalam dunia pendidikan tidak hanya berhenti pada proses mencari dan menyampaikan pengetahuan saja. Teknologi juga harus digunakan dalam proses evaluasi pembelajaran. Menurut Zainal Arifin (2009) fungsi dari evaluasi adalah mengetahui kedudukan peserta didik, mengetahui taraf kesiapan peserta didik menempuh program, membantu guru memberikan bimbingan, dan memberi laporan kemajuan peserta didik. Hasil evaluasi dapat digunakan sebagai tolok ukur keberhasilan pembelajaran yang sudah dilaksanakan sekaligus menjadi pertimbangan menentukan pembelajaran berikutnya.

Peserta didik sekarang merupakan anak-anak generasi Z, yaitu generasi yang lahir dan tumbuh di era internet. Mereka melek teknologi sehingga mempunyai ruang leluasa untuk menggapai dunia dan impiannya. (Kompas, 20 Maret 2018). Oleh sebab itu, guru sebagai salah satu komponen penting dalam dunia pendidikan dituntut untuk melek teknologi dan dapat memanfaatkannya dalam pembelajaran untuk mencetak generasi yang mampu menjawab tantangan global. 
Beberapa teknologi yang dapat digunakan untuk pembelajaran daring antara lain smartphone, smartphone atau telepon pintar yang mayoritas dimiliki dan sering digunakan oleh peserta didik maupun guru. Pengembangan media evaluasi pembelajaran berbasis TIK mulai banyak dilakukan, salah satu yang dapat dimanfaatkan sebagai media evaluasi berbasis TIK adalah Google Formulir. Google Formulir adalah bagian dari komponen Google Docs yang disediakan oleh raksasa teknologi Google. Google Formulir adalah software yang dapat diakses secara gratis dan cukup mudah dalam pengoperasiannya tanpa harus mengunduh dan menginstal suatu aplikasi, serta untuk mengatasi spesipik smartphone dari tiap-tiap peserta didik, karena link google formulir itu sendiri cukup di share melalui Whatsapp (media sosial), E-mail dan Web. Peneliti tertarik untuk membuat media dan evaluasi pembelajaran berbasis google formulir untuk membantu guru dalam menyampaikan materi dan mempermudah peserta didik dalam kegiatan pembelajaran daring selama masa pandemi.

\section{Metode Penelitian}

Berdasarkan fokus masalahnya Penelitian ini termasuk ke dalam penelitian pengembangan. maka metode yang tepat dalam pengembangan Media pembelajaran berbasis google form dalam penelitian ini dengan menggunakan langkah-langkah model Borg dan Gall yang telah dimodifikasi oleh Soenarto (2003), adapun langkahlangkah penelitian ini adalah: analisis produk yang dikembangkan, mengembangkan produk awal yang dikembangkan terdiri dari analisis concept, design, dan collecting, dan uji coba produk. Uji coba produk dalam penelitian ini terdiri dari validasi ahli dan revisi serta uji coba skala kecil dan revisi produk. Uji ahli atau validasi terdiri dari validasi media dan validasi materi yang dilakukan dengan bantuan tiga orang validator, yaitu dua orang guru produktif multimedia dan guru bidang studi matematika. Penelitian dilaksanakan di SMK Pasundan 1 Banjar secara daring dengan durasi 2 pertemuan, $(1$ pertemuan $=90$ menit $)$

\section{Hasil dan Pembahasan}

Analisis produk yang dikembangkan terdiri dari analisis concept, design, dan collecting materials. Pada tahapan analisis concept, melakukan analisis terhadap hal-hal yang diperlukan dalam perencanaan perangkat pembelajaran. Pada tahap ini, diputuskan bahwa materi yang akan digunakan adalah logika matematika 
Pada tahap analisis design, peneliti membuat rancangan tentang tampilan google form yang akan dikembangkan. Pada tahap ini, peneliti mulai merencanakan tentang judul form yang digunakan,video yang digunakan, tata letak, dan lainnya.

Pada tahap collecting materials, dilakukan pengumpulan bahan yang diperlukan untuk membuat produk. Pada tahap ini peneliti mencari video materi yang nantinya akan diunggah di google form yang dikembangkan dan latihan soal..

Mengembangkan produk awal diawali dengan membuat akun google yang akan digunakan dan selanjutnya masuk dalam google drive untuk membuat google formulir yang akan direncanakan. Selanjutnya, materi-materi logika matematika yang berupa link youtube di upload dan latihan soal diintegrasikan ke dalam google form tersebut. Hasil pengembangan tersebut adalah link google form yang telah dikembangkan adalah https://bit.ly/36Tbq1 atau

https://docs.google.com/forms/d/1J4H88

UqZV-

\section{Pobw9axkYqKYxYjxO2Twgutf6QHXic} w-U/edit?usp=drivesdk

Halaman pertama ketika kita mengakses link google form adalah halaman depan. Halaman depan berisikan tentang identitas peserta didik. Halaman depan dapat dilihat pada gambar 1 .

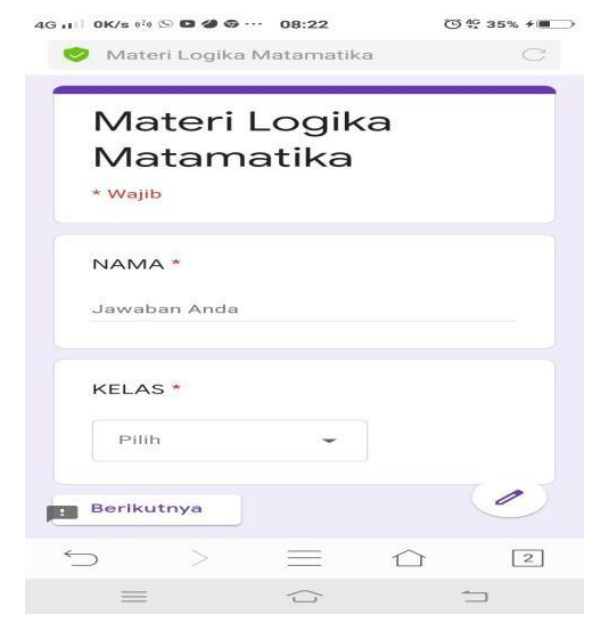

Gambar 1. Halaman depan

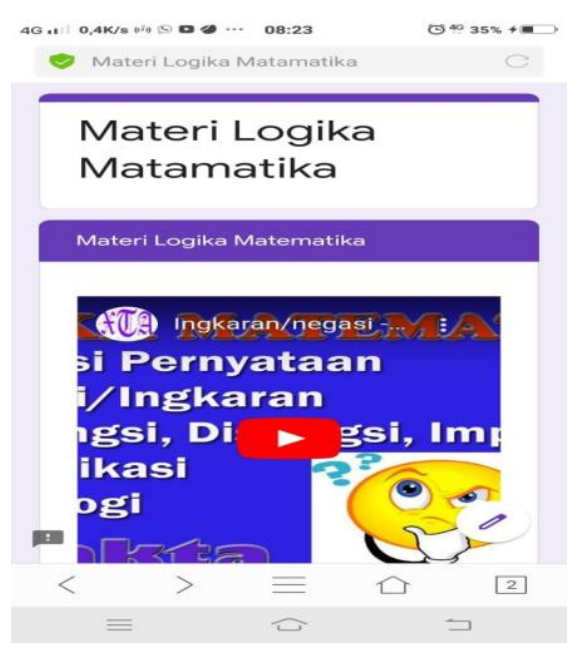

Gambar 2. Halaman Materi

Halaman kedua pada google form site ini adalah halaman materi. Halaman materi berisi 2 video pembelajaran dapat dipelajari oleh peserta didik.

Pada gambar 2, terlihat bahwa materi yang diberikan berbentuk 2 video pembelajaran yang memberikan penjelasan tentang materi logika matematika. Diharapkan dengan adanya video pembelajaran ini dapat membuat 
peserta didik tertarik dan bersemangat untuk menyimak dan memahami materi.

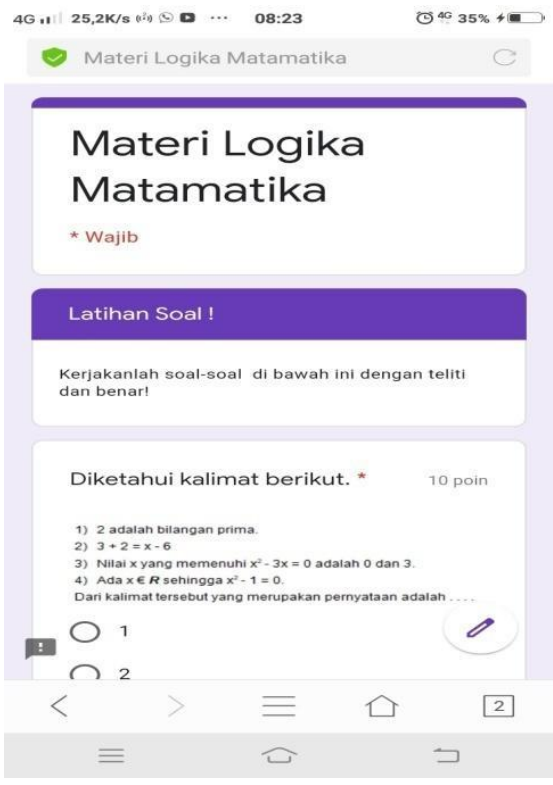

Gambar 3. Halaman latihan soal

Halaman ketiga adalah halaman latihan soal yang berisi latihan soal yang langsung bisa diakses secara online. latihan soal tentang logika matematika yang terdiri dari 10 soal pilihan ganda yang harus di kerjakan oleh peserta didik, setelah selesai mengerjakan peserta didik diharuskan untuk mengirim jawaban dengan memilih tombol kirim yang ada pada google form.

\section{Uji Coba produk}

Setelah produk awal selesai dikembangkan, langkah selanjutnya dilakukan uji coba produk yang terdiri dari dua tahap, yaitu uji ahli dan uji coba skala kecil. Uji ahli atau validasi terdiri dari validasi media dan validasi materi. Hasil penilaian validator terhadap media dapat dilihat pada Tabel 1 berikut.
Tabel 1. Hasil validasi media

\begin{tabular}{|c|c|}
\hline Kriteria yang dinilai & $\begin{array}{c}\text { Skor } \\
\text { rata- } \\
\text { rata } \\
\text { tiap } \\
\text { aspek }\end{array}$ \\
\hline \multicolumn{2}{|l|}{ Aspek tampilan } \\
\hline $\begin{array}{l}\text { Desain media sesuai dengan } \\
\text { materi logika matematika }\end{array}$ & 4 \\
\hline $\begin{array}{l}\text { Desain media menarik untuk di } \\
\text { lihat }\end{array}$ & 3 \\
\hline \begin{tabular}{l}
\multicolumn{2}{l}{ Kesesuaian tampilan } \\
dengan \\
didik
\end{tabular} & 3 \\
\hline $\begin{array}{l}\text { Kesesuaian tata letak video, } \\
\text { gambar, dan tulisan }\end{array}$ & 3 \\
\hline Aspek tulisan & \\
\hline $\begin{array}{lll}\text { Kemudahan } & \text { tulisan } & \text { untuk } \\
\text { dibaca } & & \\
\end{array}$ & 4 \\
\hline $\begin{array}{l}\text { Kemudahan kalimat untuk } \\
\text { Dimengerti }\end{array}$ & 3 \\
\hline $\begin{array}{lll}\text { Kesesuaian } & \text { warna } & \text { yang } \\
\text { digunakan } & & \end{array}$ & 3 \\
\hline$\underline{\text { Skor Kevalidan }}$ & 3,3 \\
\hline
\end{tabular}

Berdasarkan hasil Tabel 1, dapat diketahui bahwa skor kevalidan yang diperoleh sebesar (Va) 3,3. Skor tersebut menunjukkan bahwa media pembelajaran dapat dikatakan valid. sedangkan Hasil validasi ahli materi dapat dilihat pada tabel 2 berikut. 
Tabel 2. Hasil validasi materi

\begin{tabular}{lc}
\hline \multicolumn{1}{c}{ Kriteria yang dinilai } & $\begin{array}{c}\text { Skor } \\
\text { rata- } \\
\text { rata tiap } \\
\text { aspek }\end{array}$ \\
\hline $\begin{array}{l}\text { Aspek Isi } \\
\text { Kesesuaian media dengan } \\
\text { materi logika matematika }\end{array}$ & 3 \\
\hline $\begin{array}{l}\text { Kelengkapan materi sesuai } \\
\text { dengan tingkat perkembangan } \\
\text { peserta didik }\end{array}$ & 3 \\
\hline $\begin{array}{l}\text { Mendorong rasa keingintahuan } \\
\text { peserta didik }\end{array}$ & 4 \\
\hline $\begin{array}{l}\text { Materi yang disajikan sesuai } \\
\text { dengan kebenaran keilmuan }\end{array}$ & 3 \\
\hline $\begin{array}{l}\text { Aspek Bahasa } \\
\text { Keefektifan kalimat }\end{array}$ & 3 \\
\hline $\begin{array}{l}\text { Kelengkapan kalimat/informasi } \\
\text { yang di butuhkan }\end{array}$ & 3 \\
\hline $\begin{array}{l}\text { Kemudahan bahasa untuk } \\
\text { dimengerti }\end{array}$ & 4 \\
\hline Skor Kevalidan \\
\hline
\end{tabular}

Berdasarkan hasil dari uji validitas pada Tabel 2, maka dapat disimpulkan bahwa media bisa dikatakan valid dan tahap selanjutnya uji coba media.

Tujuan Uji coba ini dilakukan untuk mengetahui respon peserta didik terhadap media yang telah dikembangkan.dengan cara peserta didik diberikan angket dan diminta untuk menilai media tersebut. Penilaian tersebut didasarkan pada dua aspek, yaitu aspek desain dan aspek fungsi. Hasil analisis angket respon peserta didik dapat dilihat pada Tabel 3 di bawah ini.
Tabel 3. Hasil analisis angket respon peserta didik

\begin{tabular}{lc}
\hline \multicolumn{1}{c}{ Kriteria yang dinilai } & $\begin{array}{c}\text { Skor } \\
\text { rata- } \\
\text { rata } \\
\text { tiap } \\
\text { aspek }\end{array}$ \\
\hline Aspek Design & 3 \\
\hline Media mudah untuk dioperasikan & 4 \\
\hline Kalimat yang digunakan jelas & 3 \\
\hline $\begin{array}{l}\text { Warna, tulisan, gambar dan video } \\
\text { pembelajaran menarik }\end{array}$ & \\
\hline Aspek Fungsi & 3 \\
\hline $\begin{array}{l}\text { Media mampu memotivasi saya } \\
\text { untuk belajar matematika }\end{array}$ & 4 \\
\hline $\begin{array}{l}\text { Media mampu memberikan sarana } \\
\text { belajar materi logika matematika }\end{array}$ & 3,4 \\
\hline Skor Kevalidan & \\
\hline
\end{tabular}

Dari hasil validasi ahli media dan ahli materi serta uji coba yang dilakukan maka media pembelajaran berbasis google form pada materi logika matematika dinyatakan valid. Kevalidan media google form tersebut didasarkan pada hasil validasi ahli media dan ahli materi dengan diperoleh rata-rata skor $\geq 3$ $\geq 3$ untuk setiap aspek yang dinilai.

Hasil uji coba skala kecil media pembelajaran berbasis google form menunjukkan bahwa peserta didik memberikan respon positif terhadap setiap aspek yang dinilai. Dari hasil uji coba menunjukkan bahwa media mampu memotivasi peserta didik untuk belajar matematika. Media pembelajaran berbasis google form ini juga menyediakan latihan soal berupa pilihan ganda 
Pemanfaatan Google formulir sebagai media evaluasi pembelajaran sebenarnya tidak banyak mengalami kesulitan. Pengembangan aplikasi besutan Google ini juga tidak rumit dan sangat sederhana. Google formulir jauh lebih praktis karena tidak perlu menginstal software. Google formulir juga dapat diakses di segala tempat selama memiliki jaringan internet. Sayangnya pengembangan awal Google formulir sebagai media untuk mengumpulkan data survei dan kuesioner menyebabkan munculnya keterbatasan jika aplikasi ini dimanfaatkan sebagai media evaluasi pembelajaran.

Kelemahan pertama Media evaluasi pembelajaran yang dikembangkan dengan Google formulir belum bisa dilakukan pembatasan waktu pengerjaan soal, Admin hanya bisa membatasi waktu akses terhadap soal tersebut.

Kelemahan kedua adalah tidak ada menu untuk menandai soal mana yang sudah dikerjakan, belum dikerjakan, atau sudah dikerjakan tapi masih ragu-ragu. Cara untuk menyiasati kelemahan ini adalah mengaktifkan menu "wajib dijawab" pada setiap soal. Saat menu ini aktif maka saat peserta didik akan mengirim jawaban dan terdapat soal yang belum dijawab, formulir tidak bisa dikirim sehingga peserta didik harus mengecek satu per satu soal yang tersedia.

Kelemahan ketiga, tidak adanya simbol matematika, tetapi peneliti menyiasati dengan cara menuliskan di Microsoft Word, kemudian di ubah menjadi image dengan bantuan Apk Snipping Toll, selanjutnya di upload ke Google Formulir

\section{Kesimpulan}

Media evaluasi pembelajaran matematika berbasis google form sudah melalui tahapan validasi ahli media dan ahli materi serta masuk dalam kategori layak digunakan sebagai media evaluasi dan pembelajaran matematika dan mampu memotivasi peserta didik untuk belajar matematika. Media ini masih terbatas dalam materi logika matematika saja, oleh karena itu, peneliti berikutnya dapat mengembangkan media evaluasi pembelajaran berbasis google form pada materi matematika yang lain. prospek pengembangan dari hasil penelitian dan aplikasi lebih jauh yang menjadi prospek kajian berikutnya dan mata pelajaran lain.

\section{Ucapan Terimakasih}

Saya ucapkan terima kasih buat keluarga kecilku atas do'a dan dorongan semangatnya untuk selalu belajar \& belajar. para dosen pascasarjana dan teman teman prodi . pendidikan matematika, Universitas Siliwangi, tahun 
2019. Tidak lupa juga buat kepada pihakpihak lain yang telah membantu dalam kegiatan penelitian yang dilakukan.

\section{Pustaka}

Kementrian pendidikan dan kebudayaan.

Surat edaran no 4. Tahun 2020.

Tentang pelaksanaan kebijakan

pendidikan dalam masa darurat penyebaran corona virus disease (covid- 19)

Zaenal Arifin. 2009. Evaluasi Pembelajaran: Prinsip, Teknik, Prosedur. Bandung: Remaja Rosdakarya.

Materi Program Linear untuk Siswa Sekolah Menengah Atas. Jurnal Pendidikan Matematika, 2(2).

Soenarto. (2003). Metodologi penelitian pengembangan untuk peningkatan kualitas pembelajaran. Jakarta: Depdiknas

Umar. 2013. Media pendidikan: peran dan fungsinya dalam pembelajaran. Jurnal Tarbawiyah, 10(2).

Undang-Undang Sistem Pendidikan Nasional No.20 tahun 2003.

Tatik Sutarti. 2017. Kiat Sukses Meraih Hibah Penelitian
Pengembangan. Yogyakarta: Deepublish.

Admin Google. 2018. G suite by Google cloud, formulir. Diakses pada http://www.google.com/int1/id/f or $\mathrm{m} / \mathrm{about} /$

Dwi Purwati, Alifi Nur Prasetia Nugroho. 2018. Pengembangan Media Evaluasi Pembelajaran Sejarah Berbasis Google Formulir Di SMA N 1 Prambanan. Jurnal Istoria. UNY

aisyah trees sandy, anang kadarsah, annisau nafiah, anton kuswoyo, arief syarifuddin, eddy sutadji, estar putra akbar, feiliana tan, hilda susanti, setyabudi irawan, iskandar ahmaddien, jaka darma jaya, khomsatun ni'mah, kurnia dwi artika, laily ulfiyah, m iqbal, marlia adriana, milla milkani omarsaid, mochamad umaryaji, muhammad ghalih, nani ratnaningsih, nurfadilah siregar, nurul fadhilah, puji lestar, riana nurmalasari, rizqie mayasari, sarjono sarjono, ture simamora, wahyu lailatul rohmah, yogabakti adipradana, setiawan setiawan. 2020. di balik wabah covid-19 sumbangan pemikiran dan perspektif akademis

Ratnaningsih, n., hidayat, e., \& anisa, w. n. (2018). pelatihan pembuatan 
bahan ajar dengan menggunakan

pendekatan saintifik. jurnal pengabdian siliwangi, 4(1).

Trianto. (2011). Mendesain Model

Pembelajaran Inovatif-Progresif.

Kencana Prenada Media Group.

Jakarta 